【目的】自動前立腺マッサージより，主としてリンパ系を介した循環障害改善効果が得られることが， 前回の報告で推察され，本装直を用いたマッサーシ法の臨床的有用性が示された。今回，自動マッサ 一シ法と従来の用手マッサージ法との相違を病理組稆学的に比较検討したので報告ナる。

【対象と方法】奶象は臨床的にB P H と診断された31例で，TURPの際，マッサーシ直前，直後に超 音波カイト下に前立腺尖部浅啳よりハイオブティーガンにて組樴を採取した。自動マッサージ法21例、 用手法10例であった。自動マッサーシ法は，装置により同一条件下(マッサージ時間10分，回転数 1.2 r.p.s.，振動数 $1.8 \mathrm{~V}$ ) で行い，用手法は8の字ないし上下に10分間行った。マッサーシ值前, 直 後の組織をホルマリン固定し，HE染色後鏡䫓し比慗検討した。

【結果・考察】H E 染色による光顕レペルで、マッサージ直後の前立腺組織に，自動マッサーシ法では 16例，76\%，用手法では 5 例，50タに軽度のリンパ管払張が認められた。症例が少なくマッサージ法 による差は結論を得ないが，いずれのマッサージ法でも主としてリンハ系を介した循喂害改善奻果 が得られる可能性が推察された。

\title{
P-412 焣孟尿管移行部狭窄症における平滑筋・膠原線䊒の立体搟築と神経分布
}

\author{
北海道大学泌尿器科 ${ }^{11}$ 、同第三解剖 21 \\ 村雲雅志 ${ }^{\prime}$ 、野々村克也 ${ }^{11}$ 、牛木辰男 ${ }^{21}$ 、阿部和厚 ${ }^{21}$ 、松村欣也 ${ }^{11}$ 、松浦忍 ${ }^{\prime \prime}$ \\ 菅野贵行”、山下哲史 ${ }^{\prime \prime}$ 、小柳知彦"
}

【目的】置孟尿管移行部(PUJ) 狭窄症の病理所見としては、1)平滑筋の萎縮と配列の乱れ 2)膠原線維 の增生 3)神経終末の隇少、などが知られる。これらの所見の意義を明らかにするために、平滑筋と膠 原線維の構築の変化を調へ、さらに神経分布密度との関係を検討した。【材料と方法】Whitaker test で閉塞性を示し手術対象となったPUJ狭窄症 7 例（内因性5例、外因性 2 例）の狭窄部および非狭窄部 尿管を用いた。また非閉塞性疾患で手術を受けた 7 例のPUJを対照とした。固定した標本に 2 種類の化 学消化法を施して目的の構造を路出（KOH-コラゲナーゼ消化法で結合組織を除去、あるいはアルカリー 水細胞浸軟法で膠原線維以外の構造を除去）した後、走查電子影微鏡（日立、S-2500）で立体構築を筧 察した。また一部の標本はパラフィン包埋ののちに薄切し、U1traclone社撆抗ヒトPGP9.5抗体（神経組 織の非特異的マーカー）に対する免疫組織化学染色を施行して、神経の分布を観察した。【結果】内因 性狭窄のPUJは、正常例と比較して以下の特徽を示した：11筋束が隇少し、筋束を栗成する筋細胞数は 正常の 5 分の 1 。平漬笳細胞径は正常の 4 分の 3 で、細胞間隙は約 7 倍に開大。2)筋束内において、平 滑筋細胞周囲の膠原線維が军いフェルト状に変化（正常では織細なレース状）。3）觔届における単位面 皘当たりの神経分布密度は正常の約 3 分の1。これに対して、内因性狭窄例でも非狭窄部の尿管や、 外因性狭窄例の標本では、正常例との差異を認めなかった。【考察】平滑㙝細胞周囲の膠原細線維は筋 細胞の鞘を形成し、䇟細胞の伸展・収縮に適合した構築をなす。内因性狭窄例の PUJの筋細胞にはこの 膠原線維鞘の正常構造を保持する能力がないと考えられる。また同部の神経分布の減少は、筋細胞の失 調に神経が深く関与していることを示唆する。 